\title{
The International Human Rights Clinic at SOAS
}

\author{
Lynn Welchman
}

\section{INTRODUCTION}

The Clinic at the SOAS School of Law seems to have been the first international human rights clinic in the UK and has operated since 2007. I modelled it on human rights clinics in the United States, which are plentiful and come in different forms; according to Hurwitz, a human rights clinic is "a law school-based, credit-bearing course or program that combines clinical methodology around skills and values training with live case-project work, all or most of which takes place in the human rights context." On the "learning-by-doing" principle of clinical legal education (CLE), the SOAS Clinic tries to have students experience, through working on a real brief with real partners from real human rights nongovernmental organizations (NGOs), something of what it is like to do human rights NGO research/advocacy work (including competing demands on their time). In this chapter, I present the experience of the SOAS Clinic as well as the broader CLE context in the UK, which mostly follows different models.

The SOAS Clinic is designed to build a skills set in practical legal research and desk-based "fact-finding," report/brief writing, teamwork, and negotiating and communications skills. Through their reflection on their work during and after the process, students are expected to develop a fine-grained appreciation and critique of human rights engagement in matters of social justice and their own potential in that space. Research and advocacy briefs agreed upon with our NGO partners cover areas of international human rights law, international humanitarian law, and international criminal law; most commonly, the focus will be on application and domestic implementation of the same and strategies for seeking correction or redress. Our project partners have also sought clinic input into the development of organizational policy and priorities on particular norms and/or geographical areas of

1 Deena R. Hurwitz, Lawyering for Justice and the Inevitability of International Human Rights Clinics. 28 YALE J. INT'L L 505 (2003). See also Chapter 16 by Kjos and Nollkamper and Chapter 9 by Alemanno and Khadar in this volume. For the SOAS Clinic, see https://www.soas.ac.uk/law/international -humanrights-clinic/. 
work. Clinic students thus have the opportunity to contribute in real terms to the work of the "human rights movement" and, by so doing, inter alia, to experience the tensions of theory and practice. In times of reduced resources for the NGO sector, the Clinic students bring their time, intellectual energy, and access to substantial academic resources to a cooperative endeavour for the benefit of the partners and, ultimately, the individuals and communities they seek to serve.

The Clinic is a full year postgraduate course running for credit for LLM and MA Law students as part of our human rights and international law specialisms. ${ }^{2}$ Students in the Clinic work in small teams of up to four on research and advocacy briefs from UK- and overseas-based institutional partners engaged in international human rights work or domestic human rights work with an international and/or comparative dimension. The course is structured around a two-hour weekly seminar followed by a project hour. The seminar (Clinic "plenary") addresses a range of issues in human rights advocacy, strategies, and challenges and often involves practitioners engaged in different aspects and strategies of human rights work (mostly London-based project partners). Certain practical skills aspects are also addressed in the plenary, such as web-based research for human rights and human rights report-writing; there are structured project "rounds" sessions as well as less formal reflection periods. Students maintain a Project Diary and write a selfevaluation statement; formal assessment is conducted on the basis of a Project Portfolio, which includes these two items as well as a presentation of a selection of the student's project work (with the finished group project annexed); and, later, an end-of-course essay that has been the subject of a plenary presentation and discussion.

Over the years, our project partners have included mostly human rights organizations but also law firms with human rights specialization. Amongst others, we have worked on briefs for and with Amnesty International, REDRESS, Child Soldiers International, the Institute for Human Rights and Business, Lawyers for Justice in Libya, the Norwegian Refugee Council, Legal Action Worldwide, ASK (Dhaka), the Cairo Institute for Human Rights Studies, al-Haq and the Welfare Association (Palestine), and DC-CAM (Cambodia). Clinic project teams have addressed domestic violence legislation and policy, the protection of cultural property, violence against women, the right to water, corporal punishment, public health emergencies, disability rights, refugee and immigration detention, and a range of other matters invoking human rights as well as international humanitarian law. Clinic project teams meet with our partners for an initial briefing, with subsequent meetings agreed over the course of the project (in person or by Skype) and email

2 LLM: Human Rights, Conflict and Justice, as well as the general LLM; MA Human Rights, and MA International and Comparative Studies. As of 2016, we have had more than 130 students pass through seven Clinics. Some of the narrative here may be out of date by publication as SOAS restructures its offerings to fit the Bologna criteria or may be overtaken as the sector overall adjusts to whatever comes after the "Brexit" vote on June 23, 2016. 
correspondence in between. I supervise all the teams, with lead supervision provided for one or two teams by colleagues. ${ }^{3}$ The teams conduct their work at SOAS, unless exceptionally they are required to work in situ by partners. The outcome briefs are delivered half way through the second term and may be delivered also in presentation at meetings organized by the project partners to a wider group of their colleagues.

\section{EMERGENCE OF THE SOAS CLINIC AND THE CLE ENVIRONMENT IN UK}

\section{Genesis and Context}

The SOAS Clinic hardly fits the model of CLE more generally recognized in the UK, but it does share key features of CLE as articulated by practitioner-scholars ("clinicians") in the relevant literature. It strikes me that asserting you are involved in (or setting up) a "clinic" is a little like asserting you are involved in a "human rights organization" in terms of the self-definition and assumptions that arise and the evolving practitioner/professional consensus around what qualities may rule you in or out. For his part, Richard Wilson, from 1990 the founding director of the International Human Rights Law Clinic at the American University's Washington College of Law, tells us that "a law school can call its clinical legal education activity by any name ... so long as the focus is on student experiential learning - learning by doing - for academic credit." 4

The catalyst for my establishment of the Clinic at SOAS came directly from my continuing human rights engagement (mostly Middle East-related) after entering the academy following a decade and a half of international human rights practice working with Palestinian and international human rights NGOs (and once, for a very short stint, with the $\mathrm{UN}$ ). As an academic I was able to respond to requests from human rights organizations to act as investigator, trial observer, and other such short-term and subject-specific tasks in the field, as well as taking on more ongoing responsibilities on different organizations' Boards. I was not, however, involved in teaching human rights courses. The year 2005 saw the end of a six-year multipartner, externally funded action-oriented research and advocacy project on strategies of response to "crimes of honour" as violence against women that I had coordinated with Sara Hossain from INTERIGHTS. ${ }^{5}$ For me, this left a gap in institutional resources or structures through which to engage in sustained cooperation with individuals and organizations who had been our project partners, as well as others

3 Iain Scobbie and Lutz Oette.

4 Richard J. Wilson, Western Europe: Last Holdout in the Worldwide Acceptance of Clinical Legal Education, 10 (7)German LaW Journal 823-46 (2009), at 829.

5 See Lynn Welchman and Sara Hossain, eds. "Honour": Crimes, Paradigms and Violence Against Women (London: Zed Books 2005). 
with whom I had established relationships. At the same time, like other colleagues, I was concerned by the increasing expectation on graduates that they secure unpaid internships in expensive capital cities if they were to position themselves most favourably for paid openings in human rights work. I took the actual decision to establish a Clinic at SOAS as the direct result of ruminations with an Amnesty friend in a hotel room in Sana'a in early 2006, waiting for a call from the authorities in Political Security to confirm a visit to detainees who had been returned to Yemen after extended periods in "black sites" under CIA authority, as part of the extrajudicial rendition programme in the "war on terror." 6

Back in SOAS, I found solid support among some colleagues, particularly those themselves in positions of "engaged" or policy-related scholarship; volunteerism was and is very much a feature of the Clinic. ${ }^{7}$ Friends and colleagues in and from the NGO human rights movement in the Middle East and South Asia were enthusiastic and interested in various forms of cooperation; colleagues running clinics gave advice on things to do and things to avoid, ${ }^{8}$ and, while in Ramallah, I was further inspired by the energies of colleagues establishing the first human rights clinic in Palestine at the university of Al-Quds. ${ }^{9}$ In terms of scholarship, I drew particularly on literature from human rights clinicians in the United States. ${ }^{10}$ There is considerable reflection on "the deepening convergence of international law and clinical legal education in the United States" in the realm specifically of international human rights. ${ }^{11}$ In 2010, Richard Wilson introduced "the first panel on clinical legal education in the Society's history" at the annual meeting of the American Society of International Law - again, emphasizing the relatively recent inclusion of CLE as

6 See Amnesty International, Below the Radar, 5 April 2006. (AI Index AMR 51/051/2006), 9-17; and see Al-Asadv Diibouti, a complaint at the African Commission on Human and People's Rights, submitted following his release by one of these detainees through New York University's Global Justice Clinic and INTERIGHTS (the International Centre for the Protection of Human Rights), seeking relief for secret detention, ill-treatment, and refoulement.

7 In particular, the team from the Hotung Project on Law, Human Rights, and Peace-Building in the Middle East: Iain Scobbie, Stephanie Koury, Ron Dudai, and Sarah Hibbin. Stephanie and I worked closely together in the establishment stage; Sarah volunteered with the Clinic until she left SOAS; and Iain still participates, as does Ron if he is in town. Joyce Song volunteered with the Clinic while in London as a New York lawyer.

8 In particular, Deena Hurwitz, then at Virginia; I worked with Deena in Palestine in the mid-199os.

9 See David Chavkin, Thinking/Practicing Clinical Legal Education from within the Palestinian-Israeli Conflict: Lessons from the Al-Quds Human Rights Clinic, 18 Human Rights Brief 14-18 (2010); on legal clinics in Hebron and more generally, see Mutaz Qafisheh, Modern Legal Education in Palestine: The Clinical Programs of Hebron University, in ExPerimental Legal Education in a Globalized World. The Middle East and Beyond (Mutaz M. Qafisheh and Stephen A. Rosenbaum, eds. (Newcastle upon Tyne: Cambridge Scholars Publishing, 2016), 198-235.

10 Notably, Deena Hurwitz, Lawyering for Justice and Inevitability of International Human Rights Clinics, 28 Yale J. InT'L. L. 505-50 (2003); Arturo J. Carillo, Bringing International Law Home: The Innovative Role of Human Rights Clinics in the Transnational Legal Process, 35 Colum H. RTs. L. Rev. 527-87 (2003-2004); Peter Rosenblum, Teaching Human Rights: Ambivalent Activism, Multiple Discourses and Lingering Dilemmas, 15 Harvard Human Rights Journal 301-15 (2002).

11 Carillo, supra note 10 at 527 . 
a "method or philosophy of law teaching" and the "even more recent development within the clinical teaching movement" - that is, international law and, in particular, international human rights law. In his 2009 address in the German Law Journal, Wilson had suggested that "work in the area of human rights protection may provide a beachhead for clinical innovation" in parts of Europe that his title described as the "last holdout" against CLE. ${ }^{12}$ He exempted the UK from these remarks, given that there has been a more or less active clinical movement here for a couple of decades, preceded by remarkable initial ventures in the 1970 .

We spent considerable effort trying to secure funding for a pilot phase of the Clinic at SOAS and drafting course proposals to be put through the various processes of approval. The proposal that was finally approved stated under "additional resources needed" that we were seeking external funding for a three-year post for one full-time staff member for the Clinic and that "the operation of the Clinic as of September 2007 will be dependent on securing this funding." We failed to secure funding, but external factors combined to prompt us to launch the Clinic anyway, and, happily, nobody who might have stopped us invoked the caveat about external funding. The University of London LLM was devolving to individual colleges and schools of the University, and, at SOAS, a comparatively small college, we were nervous about the impact on student recruitment when the attraction to students of being able to take two of their four LLM courses at other London colleges ceased to be a part of our offering. The decision on timing - that is, to proceed with existing resources and launch the Clinic that particular year - was part of an effort to enhance our profile for postgraduate students (both LLM and MA Law) in that context. In different ways then, the origins of the SOAS Clinic illustrate the observation that Clinics in the UK are "usually bespoke creations to meet the demands defined by individual Law Schools."13

\section{Drivers}

The editors of Britain's first student handbook on CLE are no doubt correct in saying that it is "in-house advice and representation clinics" that are "often viewed as the gold standard of law clinics" in the UK context. ${ }^{14}$ Indeed, the fact that there exists a student handbook on CLE tells one part of the story of the current state of the field in the UK - the current diffusion and rise in CLE offerings, mainly to undergraduates but increasingly also to postgraduates. In 2015, Drummond found 102

12 Wilson, supra 4 note at 828 , and see 844 .

13 Orla Drummond and Gráinne McKeever, Access to Justice through University LaW Clinics (Ulster: Ulster University Law School 2015), www.ulster.ac.uk/lawclinic/files/2014/o6/Access-to -Justice-through-Uni-Law-Clinics-November-2015.pdf, 5.

14 Kevin Kerrigan, What Is Clinical Legal Education and Pro Bono?, in A STUdent GUide to CuiniCaL Legal Education and Pro Bono (Kevin Kerrigan and Victoria Murray, eds., Houndmills: Palgrave Macmillan 2011), 1-20, at 1. The handbook chapters are contributed by staff members of the clinic (the Student Law Office) at the University of Northumbria's School of Law. 
law schools in the UK, of which sixty-four had "clinic-related activities." found to constitute an overall increase in university law clinics since the 1990s, with an acceleration from 2000-2010 and again from $2011-2015 .{ }^{16}$ A 2014 LawWorks report which followed up previous surveys on law school clinical and pro bono work deduced from the responses to its survey that "at least $70 \%$ of all law schools are now involved in pro bono and/or clinical activity." ${ }^{\prime 7}$ This was found to be a "marginal" increase (of 5\%) over the findings from the previous 2006-2010 survey, which itself had shown an increase of $33 \%$ of the survey before that. ${ }^{18}$ The increase may be predictably slowing, but it is surely indicative of a "mainstreaming" of CLE in UK university law schools that CLE pioneers here in the early 1970s might have aspired to, albeit without wishing upon us the attendant squeezes that appear to have given impetus to the current acceleration. These include severe reduction in government-funded legal aid provision and the imposition of undergraduate student fees (of up to $£ 9,000$ p/a from summer 2012 ) (19 $^{19}$ along with significant austerity impacts in state funding of the higher education sector as a whole. Just shy of two decades of existence as an informal, umbrella grouping of those interested in CLE in the UK, in 2014 it was announced that the Clinical Legal Education Organization (CLEO) was applying for incorporation as a charitable organization, inter alia because "there is now ... a critical mass of law schools and individuals involved in clinic to make wider representation appropriate and feasible." ${ }^{20}$

On the scholarship side, there is a "surfeit of literature" on the "many different nuances of clinical legal education," facing CLE remains its scholarly place in the academy with a home discipline, law, that has had to struggle to establish its own intellectual corner recently enough to be prickly about developments that might appear to associate it too closely with "practice." And this relationship, between those involved with the "science of law" in the universities of England and Wales (a twentieth-century development) ${ }^{22}$ and those practising it as barristers and solicitors, has been a key moulding factor in the

15 Drummond and McKeever, supra note 13, at $16 . \quad{ }^{16} \quad$ Id.

17 Damian Carney, Frank Dignan, Richard Grimes, Grace Kelly, Rebecca Parker. The LawWorks LaW School Pro Bono and Clinic Report 2014. LawWorks: LexisNexis (2014), https://www.lawworks.org .uk/sites/default/files/LawWorks-student-pro-bono-report\%202014.pdf, 4.

18 See also Lydia Bleasdale-Hill and Pail Wragg, Models of Clinic and Their Value to Students, Universities and the Community in the post-2012 Fees Era, 19 IJCLE 257-69 (2013), at 257.

19 Id.

20 Carney et al., supra note 17, at 43; see Richard Grimes, Joel Klaff, and Colleen Smith, Legal Skills and Clinical Legal Education: A Survey of Undergraduate Law School Practice, 30 The LaW Teacher 44-67 (1996)at 67, noting the formation of CLEO.

21 Malcolm M. Combe, Selling Intra-curricular Clinical Legal Education, 48 (3) The LaW Teacher 281-95 (2014), at 282. And see Neil Gold and Philip Plowden, Clinical Scholarship and the Development of the Global Clinical Movement, in The Global Clinical Movement (Frank Bloch, ed., New York: Oxford University Press 2011), 311-21.

22 Anthony Bradney, Ivory Towers and Satanic Mills: Choices for University Law Schools, 17 (1) STUdies in Higher Education 5-20 (1992), at 7. See also Neil Gold, Why Not an International Journal of Clinical Legal Education?, 1 IJCLE 7-12 (2000), at 8. 
development of CLE here. Bradney observes that the use of term "science of law" "indicates a belief that the academy should be divorced from the profession." 23 Legal scholarship had no intellectual tradition at universities and so the impetus was to insist on the academic content of law and to distance the discipline from the profession. Legal academics did not (and do not) have to be qualified to practise the law in order to teach it at university; law practitioners did not (and do not) have to have an undergraduate degree in law in order to practise the profession. ${ }^{24}$ Indeed, they did not have to have an academic degree at all until the introduction of a "graduate entry" requirement for the vocational stages of legal education following the 1971 government-commissioned Report of the Committee on Legal Education (the "Ormrod Report" after the Committee's chair). ${ }^{25}$ At the moment, the postgraduation route to qualification as a solicitor or barrister involves a year of vocational or practical training followed by a period of "apprenticeship" under the supervision of qualified practitioners and their regulatory authorities. ${ }^{26}$ University students can opt for a non-law degree at undergraduate and then study law for a graduate diploma before proceeding to the vocational stage of practical training, or they can choose an undergraduate Qualifying Law Degree (its compulsory elements identified by the professional societies for certification) that qualifies them to pass directly to the vocational training stage after graduation. ${ }^{27}$

This means that there was (and is) "less focus on the 'practice gap' as a driver" for CLE in the British legal education system, as the vocational stage is precisely aimed

23 Bradney, supra note 22, at 9.

24 Twining says that some in other jurisdictions (still) find this "bizarre"; see William Twining, LETR: The Role of Academics in Legal Education and Training: 10 Theses, 48 (1) THE LAW TEACHER 94-103 (2014), at 99. Folsom and Roberts observe that this major recommendation by Ormrod was "accepted by the Bar and begrudgingly by the Law Society," continuing that "the most significant consequence of 'graduate entry' [...] is the initial selection of potential members of the legal profession through national competitive university admissions processes and the exposure of many of these students to legal academics"; see Ralph Folsom, and Neal Roberts, The Warwick Story: Being Led Down the Contextual Path of the Law, 30 Journal of Legal EduCATion 166-83 (1979), at 169.

${ }_{25}$ Folsom and Roberts (Id. note 24 at 169). The year 2016 is seeing the introduction of (/reversion to) nongraduate entry to the profession of solicitor through Trailblazer Apprenticeships, described by the Law Society as "new legal apprenticeships" providing an "alternative to the traditional graduate route to qualification” and not requiring the apprentice to study for a degree. See www.lawsociety.org.uk /Law-careers/Becoming-a-solicitor/Routes-to-qualifying/.

26 See Alemanno and Khadar, Chapter 9 in this volume, for Europe-wide comparison and also for the implications for the "social justice or public interest aspects of EU law" of the accelerated legal practice course being offered by "consortiums of large law firms" in the UK.

27 The Solicitors Regulation Authority has been consulting on proposals to more broadly remove the requirements for graduate entry to the profession of solicitor (with a few exceptions). Critiques by Burrows and Bradney are published in The Reporter; see Anthony Bradney, Professional Education for Solicitors and the Whimsical World of the Solicitors Regulation Authority, 52 ThE RePorTER: Newsletter of the Society of Legal Scholars 4-5 (spring 2016). Bradney's opening paragraph (at 4) asks "Why continue with a system that most people are largely content with when you can have all the fun of introducing something that no-one understands and few want? That is what the SRA intend to do with their new scheme for the Solicitors Qualilfying Examination [... .". 
at preparing incoming students for professional practice. ${ }^{28}$ In 1971, the Ormrod Report held that '[ $\mathrm{t}]$ he traditional antithesis between 'academic' and 'vocational', 'theoretical' and 'practical', which has divided the universities from the professions in the past, must be eliminated by adjustment on both sides." ${ }^{29}$ Bradney, whose consideration of the relationship between universities and industry or the professions is a case study of the history of university law schools in this regard, concludes that despite other "vocational pressures" in the 1980s, and although some would disagree with him, "there is much ... to lead one to see the last few decades as a period in which university law schools have distanced themselves from the legal professions." "3० For his own part he holds "it is possible to argue that the course pursued by university law schools is the only principled path that they could have chosen." 31

This is a slightly different part of the context of clinic, but still relevant given ongoing debates over the ethos of the CLE movement. A near-contemporary critique of curriculum reform and the early CLE programme at Warwick University School of Law insisted:

some of the most strongly articulated demands for more relevant courses in law schools come from radical students. But the fact that in law at least, their demands are being met does not herald the increasing "radicalisation" of the law but rather its increasing professionalisation. This means that those who have as their aim radicalisation are, paradoxically, at one with the most austerely professional lawyers, whose orientation is anything but radical..$^{2}$

The reader is referred here to the Ormrod Report, noting that inter alia, the Committee recommended "that the possibility of running legal aid clinics should be explored." 33 The critique just quoted was named for an earlier book-length comment considering the attempts by the founders of Warwick University (in the 1960s) "to make their institution 'useful' to 'business interests." 34 The Ormrod report was itself a product of a social and political context where, as described by Giddings et al., "[u]nmet legal need had become a rallying call for those seeking further welfare reform." 35 In the early seventies, the law schools of Warwick and Kent were

28 Gold and Plowden, supra note 21, at 313. See also Jeff Giddings, Roger Burridge, Shelley A. M. Gavigan, and Catherine F. Klein, The First Wave of Clinical Legal Education. The United States, Britain, Canada and Australia, in The Global Clinical Movement (Frank Bloch, ed., New York: Oxford University Press 2011), 3-22, at 14-15.

29 Cmnd 4595 (Report of the Committee on Legal Education) 1971, para.85; cited by Bradney, supra note 27 , at 9 .

$30 \quad$ Id., at $12 .{ }^{31} \quad I d$., at 15 .

32 Zenan Bankowski and Geoff Mungham, 'Warwick University Ltd.' (Continued), , British Journal of LAW AND SOCIETY 179-84 (1974), at 184 (emphasis in original).

33 Id., at 184; citing Cmnd. 45951971 para. 185. $34 \quad$ Id., at 179.

35 Giddings et al., supra note 28, at 6. Examining the latest (2013) report on legal education and training, Leighton notes that the 1971 Ormrod report "set the tone and structure for legal education in England and Wales that broadly operates today"; see Patricia Leighton, Back from the Future: Did the LETR Really Prepare Us for the Future?, 48 The LaW TEAChER 79-93 (2014), at 79. 
the first to embark upon CLE ventures in the UK, inspired according to Richard Grimes (for decades, a leader of CLE in the UK) by the examples being set in the USA, although Grimes stresses a significant difference in that "providing a service to meet legal need was not a driving force" even if much of the case work was "welfareoriented." Rather, staff and students in these law schools, coming out of the energy of student activism in the sixties, were "driven both by recognition of the pedagogic value of this approach to study but also by the focus of the law schools in question on the importance of studying law in its political, social and economic context." ${ }^{6}$ A 1979 analysis includes in the environment surrounding the creation of early clinics the recognition of law degrees from a substantial number of colleges and polytechnics and the establishment of a dozen new university law schools. ${ }^{37}$ Both the polytechnics (which later became "new" universities) and what were then new universities came to be significant actors in the CLE movement in England and Wales. $^{3}$

There are in-depth accounts of the programmes at Kent (the first to incorporate its Clinic into the undergraduate curriculum, in 1973) and at Warwick (1975).39 The Kent clinic (built around the concept of "praxis") experienced internal political struggles, external concern (including from certain local legal practices concerned about prospective competition from the live-client advice programme at the clinic), ${ }^{40}$ and also concern from the university authorities who were "unhappy with the political and public nature of the cases taken on by the clinic" as well as with the fact that some of them were directed against the university itself. ${ }^{41}$ The clinic closed in 1976; Sherr observes that "[ $t$ ] he reasons for this infant mortality were probably more closely related to the success of that enterprise, as intended, than

${ }^{6}$ Richard Grimes, Learning Law by Doing Law in the UK, I IJCLE $54-57$ (2000), at 55. Sherr notes that the Warwick Legal Practice Programme explained its aims as "building on the existing Warwick emphasis of 'law in action' and 'law in context"; see Avrom Sherr, Clinical Legal Education at Warwick and the skills Movement: Was Clinic a Creature of Its Time, in FronTIERS OF LEGAL Scholarship. Twenty Five Years of Warwick Law School (Geoffrey P. Wilson, ed., Chichester: John Wiley and Sons 1995), 108-119 at 108. The "law in context" approach was also framed by its proponents in light of experiences in post-colonial African states as well as in the US and elsewhere: Id., at 114; Twining supra note 24, at 94; Folsom and Roberts, supra note 24, at 172-73. Twining (then at Warwick) describes himself as one of the "noisy young agitators" involved in this intellectual venture.

37 Folsom and Roberts, supra note 24, at 171.

$3^{8}$ See Kevin Kerrigan and Victoria Murray, eds. A Student Guide to Clinical Legal Education and Pro Bono (Houndmills: Palgrave Macmillan 2011), at 10.

39 See Giddings et al., supra note 28, at 6; William M. Rees, Clinical Legal Education: An Analysis of the University of Kent Model, 9 THE LAW TEACHER 125-40 (1975) (in part responding to Bankowski and Mungham, supra note 32); Folsom and Roberts, supra note 24; Sherr, supra note 36.

$4 \circ$ See Frank Dignan, Bridging the Academic/Vocational Divide: The Creation of a Law Clinic in an Academic Law School, 16 IJCLE 75-84 (2011), at 83 on the "mutually advantageous" relationship that the Legal Advice Clinic at Hull has been careful to establish with "existing advice providers."

${ }^{41}$ Giddings et al., supra note 28, at 7, 11. See, by way of comparison, the website of the Essex University Law Clinic (offering "free initial legal advice"): "We also cannot assist any person wishing to pursue a claim against the University, its governors, employees or students": https://www.essex.ac.uk/law /about/clinic.aspx (last visited April 29, 2016). 
its failure" ${ }^{\prime 2}$ and goes on to note the different ways in which the Legal Practice Programme developed at Warwick (for example, according to Sherr, it was "less public and less openly principled"). ${ }^{43}$ The Kent clinic reopened in the 199os, when Grimes reports there was a "flurry of activity on the clinical front," with leading roles played by the law schools at two more (then) new universities. ${ }^{44}$ In 1995, Grimes wrote of "a discernible call for clinical legal education," noting a series of statements and positions from different government departments as well as the Law Society for further changes in the education of lawyers (this with a focus on skills, discussed further later) and the appointment of a review committee in $1994 .{ }^{45}$ Grimes was involved in a survey on skills teaching in law schools carried out in 1994, in which $83 \%$ of those who responded indicated that they offered skills teaching, although only eight hosted real client clinics. ${ }^{46}$ Consultations around legal education in the initial (academic) stage, under the auspices of the Lord Chancellor's Advisory Committee (ACLEC), were ongoing, and there was an early reference to "the value of clinical teaching, and how it might be funded." 47 The ACLEC's First Report was published in 1996, and Grimes wrote regretting its lack of attention to CLE as an "alternative but complementary" teaching method in law degrees. ${ }^{4}$ Webb argued at the same time that the report's emphasis on ethics signalled a "significant opportunity" to promote CLE as a methodology, and Clubb identifies other emphases on legal education to which CLE could contribute distinctively; he credits this as a factor in the increased inclusion of CLE in the undergraduate curriculum. ${ }^{49}$ The continuing increase in

42 Sherr, supra note 36, at 108, citing Sherr, Client InTERviEwing for Lawyers (Sweet and Maxwell 1986), vii.

43 Sherr, supra note 36 , at 113.

44 Grimes, supra note 36, at 55 . University of Northumbria at Newcastle and Sheffield Hallam; Grimes was himself involved with both at different times. He also refers to real-client clinics established in the 1990s in the Universities of Plymouth and Central England; Giddings et al., supra note 28, at 6, note "other early clinical ventures" at the polytechnics of South Bank and Trent and the University of Brunel.

45 Richard Grimes, Reflections on Clinical Legal Education, 29 THE LAW TEACHER 169-88 (1995), at 169. This article mostly reflects on the establishment in 1993 and first two years' work of the Law Clinic at Sheffield Hallam University, but the first section responds to critiques of CLE by Bradney (supra note 27) among others which he includes as part of what he describes as a "lively (if not yet extensive) debate on the relevance and content of legal skills programmes."

$4^{6}$ Grimes et al., supra note 29, at 48 .

47 ACLEC (Lord Chancellor's Advisory Committee on Legal Education and Conduct), Annual RePorT FOR 1993-1994 (London: HMSO 1994), 28 para.10.3.vii.

$4^{8}$ Richard Grimes, The ACLEC Report - Meeting Legal Education Needs in the $21^{\text {st }}$ Century?, 7 (2) Legal Education ReVIEW 281-89 (1996), at 289. Twining (supra note 24, at 94) opens his reflection on the 2013 LETR report by noting that "I have measured out my professional career with reports relating to legal education" which he says since he started teaching in the UK in 1966 "has been under almost continuous review."

49 Julian Webb, Inventing the Good: A Prospectus for Clinical Education and the Teaching of Legal Ethics in England. 30 LaW Teacher 270-94 (1996), at 271; Karen Clubb, Masters of Our Destiny The Integration of Law Clinic into Postgraduate Masters Provision, 19 IJCLE 395-404 (2013), at 397. See also James Marson, Adam Wilson, and Mark Van Hoorebeck, The Necessity of Clinical Legal Education in University Law Schools: A UK Perspective, 7 IJCLE 29-43 (2005); Giddings et al., supra note 28 . 
the new century in the number of law schools offering "clinic-related activities" has already been noted. ${ }^{\circ}$ In their 2011 overview of developments, Giddings et al. note the range of different activities that developed and were carried out as part of CLE in the UK; with CLE in its fifth decade here, they locate these as a result of "new blood, adjusted pedagogical objectives, resource pressures, educational policy and political expediency." 51

Currently, there is significant support for the development of CLE activities and an emphasis on student (and practitioner) involvement in pro bono activities. ${ }^{2} \mathrm{~A}$ set of prizes and awards recognize the work of student law clinics and pro bono work. ${ }^{53}$ Encouragement of CLE has been traced inter alia to a focus on developing skills, to government's desire for cooperation between universities and industry, and to what Benneworth and Osborne identify as the Europe-wide and economic developmentrelated "innovation imperative." 54 In the UK, the focus on "employability," undergraduate tuition fees, league tables, and consumerism trends at university 55 might support response to student demand if clinics are seen to increase employability, but they do not further the older "values" underpinning of CLE in England and Wales..$^{56}$ And certainly, a challenge remains in the fact that among subjects taught at university, law is still in the lowest funding band, and "[p]rofessional supervision of student case work by clinical teachers for large numbers of students has always fared badly in comparison with the traditional 'pile them high and teach them cheap' lecturing model." 57

\section{REFORMING THE TEACHING AND PRACTICE OF LAW IN EUROPE}

\section{Goals and Methods}

In July 2015, the Quality Assurance Agency published its third iteration of the Subject Benchmark Statement for Law, ${ }^{8}$ which titles the benchmark outcomes,

50 Drummond and McKeever, supra note 13; Carney et al., supra note 17. Infra Section 2.

${ }^{51}$ Giddings et al., supra note 28, at 6. The most recent report of significance to legal education is the Legal Education and Training Review (J. Webb, J. Ching, P. Maharg and A. Sherr, Setting Standards: The Future of Legal Services Education and Training Regulation in England and Wales (London: Legal Education and Training Review 2013); see examination in Leighton, supra note 35.

52 Giddings et al., supra note 28, at 10.

53 For example, the LawWorks and Attorney-General Student Pro Bono Awards.

54 Paul Benneworth and Michael Osborne, Knowledge, Engagement and Higher Education: Contributing to Social Change, in Higher EduCATION IN THE WORLD 5 (Global University Network for Innovation 2014), 219-32, at 221.

55 See Leighton, supra note 35 , at 88.

${ }^{6}$ See Marson et al., supra note 49; Drummond and McKeever, supra note 13, at 13; Leighton, supra note 35 , at 80 .

57 Giddings et al., supra note 28, at 10. See also Drummond and McKeever, supra note 13, at 6; and Marson et al., supra note 49 , at $41-42$ on arguments for rebanding. Compare Uitz and Polgári, Chapter 12 in this volume, on clinic demands on faculty.

$5^{8}$ This time covering Scotland as well. See www.qaa.ac.uk/publications/information-and-guidance /publication?PubID=2966\#.VyNoLuwbIU. 
for the first time, as "a law student's skills and qualities of mind." The statement continues:

By qualities of mind, we mean the intellectual abilities and attributes of graduates in law including but not limited to legal knowledge and understanding. Accordingly, we have kept references to knowledge and understanding from previous Law Subject Benchmark Statements, but we have added references to selfmanagement and academic integrity. 59

Law schools across the UK will be considering the revisions made to the Benchmark Statement and its implications for the likely quality assessment of their provision in the coming years. For law schools offering clinical options, the inclusion in qualities of mind of "self-management, including an ability to reflect on their own learning, make effective use of feedback, a willingness to acknowledge and correct errors and an ability to work collaboratively" are all potentially relevant. In their zoll guide to CLE, Kerrigan and Murray spend several pages explaining to the undergraduate student reader how a clinical experience can enhance their learning and help them to meet the goals set out by the quality controllers of undergraduate law degrees. ${ }^{60}$ Of particular significance in the 2015 Statement is the explicit inclusion of "experiential learning" as one among other possible teaching methods for students of law. ${ }^{61}$

Since the Statements apply to undergraduate degrees, they are not directly relevant to the goals we set for the SOAS Clinic. I set out earlier (in the Introduction) what we hope the students will experience and achieve in taking the Clinic as one of their courses. We do not teach the fundamentals, the substance, of international human rights law. ${ }^{62}$ Students participating are normally expected to already have a familiarity with international law or human rights law, or to be acquiring such familiarity through other School of Law courses during their degree. Our "learning outcomes" are formally identified as the following:

[by the end of the course] students should have an understanding of the rigours and challenges involved in international human rights practice and be equipped to research and write on this area; understand the dynamics of team work; be able to conduct research, individually and in teams, on case-specific themes and country situations, through a variety of media and sources, including web-based resources; understand, and be able to analyse, the application of international human rights instruments in and to specific situations; and be able to reflect constructively on the

59 Id., 4-5. 6o Kerrigan and Murray, supra note 38, at 13-15.

61 QAA Subject Benchmark Statement Law 20158 para.3.3. Clubb notes that the Joint Academic Stage Board (JASB) Handbook (for 2011) does not prescribe methodologies through which law courses are to be delivered by certified institutions; and thus "although clinical legal education is valued as an experiential learning model it is not currently a mandatory requirement of qualifying law degrees in England and Wales"; see Clubb, supra note 49, at 396. This remains the case under the more recent Handbook (BSB and SRA 2014, 4 para. 2.a).

62 Whether or not to attempt to do this is a discussion among US international human rights clinicians, who take different approaches. See Hurwitz, supra note 10, and Rosenblum, supra note 10. 
dynamics involved in building and sustaining relationships with partners in a variety of countries and situations. ${ }^{63}$

In specific regard to human rights, my aim is that my students, enrolled as they are on postgraduate programmes of international (human rights) law, learn the prospects for empowerment and remedy that the law may offer alongside "the limited value of legal action" 64 and the complexities involved in developing advocacy strategies to access legal as well as other forms of remedy. The methodologies through which the SOAS Clinic seeks to have its students achieve the goals combine a number of established clinical practices, and we have also had to make decisions about challenges that have faced other clinics and have been resolved in different ways. I will consider three issues here: the composition of the Clinic, teamwork, and assessment and reflection.

To start at the beginning, it is usually not possible to accommodate in the Clinic each year all the students who wish to take it as part of their LLM/MA. Class size limitation has been discussed since early clinic days in England and Wales and often applies whether or not participation is assessed. ${ }^{65}$ In Clinic 1, we set a maximum of fifteen students; in my most recent class (Clinic 7), the largest to date, I had twentyfour students, assigned to six project teams of four. ${ }^{66}$ Considerable flexibility has been required from SOAS central and faculty support in order to exempt the Clinic from the preterm online sign-up procedures that now otherwise apply; online signup is taken as an expression of interest in taking the course but does not guarantee a place in the Clinic. After the first class of term, where I have introduced the concept of CLE, the SOAS Clinic, and the projects for that year, I make available on the Clinic's electronic learning site a form for application and return by those who wish to sign up for the class. The form includes a statement as to motivation as well as space to detail previous or ongoing voluntary commitments and/or human rights experience (broadly writ). ${ }^{67}$ Also in that first class, I invite graduates from the previous year's Clinic to address prospective Clinic students in a question-andanswer session (from which I withdraw), which has proved very popular and which I have found to enhance diversity in the composition of the incoming class. ${ }^{68}$ On receipt of the applications, I assign students to teams on the basis of

63 International Human Rights Clinic - Introduction 2015-16, https://www.soas.ac.uk/law/international -humanrights-clinic/.

64 Grimes, supra note 45, at 171.

65 See Rees, supra note 39, at 138-39. Dignan, supra note 40, at 79 (assessed); Cardiff Law School Law Clinic (extracurricular, see website).

66 Undergraduate Clinics may use the designation "firms." See Dignan, supra note 40, at 79; Elaine Campbell, Transferring Power: A Reflective Exploration of Authentic Student-Centred Small Group Work in Clinical Legal Education, 22 IJCLE 1-31 (2015).

${ }_{67}$ Compare Chapter 16 by Nollkaemper and Kjos and Chapter 12 by Uitz and Polgári in this volume.

68 Clinic students have come from majority and BME communities in the UK and from states in Europe and North America, as well as from Middle Eastern, African, South Asian, East Asian, and Australasian states. 
the fit with the project briefs, having regard as far as I can to a set of variables including proportionate LLM/MA representation, individual student's interests and background, and abilities in languages other than English; on gender diversity, I have to report that only rarely have men applied in sufficient numbers to have one in each team.

The expansion in SOAS Clinic numbers has been due to student demand and growing interest among partners and to the fact that my line managers have allocated me a certain number of weekly "tutorial" hours in recognition of the amount of time spent in project supervision. This does not match the actual time spent (this Clinic is as labour intensive as all others appear to be), ${ }^{6}{ }^{6}$ but it does formally account for enough of my time to release me from other teaching during the first term when the project work is most intense..$^{70}$ In 2000, in the opening practice note contributed to the first edition of the International Journal of Clinical Legal Education, published at Northumbria, Richard Grimes reported on "a significant shift in attitude" in regards to the obstacles that law school lecturers perceived in establishing programmes of CLE:

Those who did not run clinics thought that set up and running costs would be the principal difficulty. Those that did have clinics operating saw the amount of staff time as the major cause for concern. ... The hard fought battles over pedagogic relevance of clinical education may now be largely a thing of the past. The debate seems to have moved on to resources and funding issues and to ensuring that the maximum benefit is extracted from clinical activity for all relevant stakeholders. ${ }^{71}$

A second critical issue is that of teamwork and the management of that process by the clinical supervisor. ${ }^{72}$ The research and advocacy brief that I have agreed with the project partner before term starts is, for each team, the basis of the first engagement with the partner and may involve negotiation as well as clarification in the first meeting. Usually, the team members do not already know each other, and they work in a flat structure: there is no designated "team leader" (except, in various capacities, myself). Working in this team, they learn to negotiate with each other and with the partner, to order and minute meetings and follow-up action agreed upon, and the other skills that come from working collaboratively and intensively together over a period of some four months. Every few weeks, the Clinic plenary is given over to

69 For examples, see Chapter 12 by Uitz and Polgári in this volume.

70 Two colleagues are also allocated a one-hour tutorial a week over the period of project work.

${ }^{71}$ Grimes, supra note 36, at 56 .

72 See McAllister (1997) 53-59, summarized in Judith Gowland and Paul McKeown, Working with Your Supervisor and Others, in A Student Guide to Clinical Legal Education and Pro Bono (Kevin Kerrigan and Victoria Murray, eds., Houndmills: Palgrave Macmillan 2011), 88-106, at 89, for an insightful consideration of the different and sometimes conflicting roles of the clinic supervisor, and the importance of the role model. See further Jeff Giddings, The Assumption of Responsibility: Supervision Practices in Experiential Legal Education, in Experimental Legal EduCation in a Globalized World. The Middle East and Beyond (Mutaz M. Qafisheh and Stephen A. Rosenbaum, eds., Newcastle upon Tyne: Cambridge Scholars Publishing 2016), 29-52. 
Project Rounds, with each team presenting and reflecting on the progress on their work (including the relationship with their project partner) and receiving feedback from the Clinic as a whole. In between, they meet with me and with the project partner or follow up meetings by email and/or Skype. In depth feedback is provided on all drafts of the project work. Although by now I can predict fairly accurately at what point(s) project teams will begin to regret having signed up for the Clinic, overall and certainly by the end "[m]ost students find the experience more intense and engaging than other law school coursework." 73 The explicit idea of commitment (to the project, the team, the partner, and the Clinic as a whole) drives the Clinic for the best part of two terms.

The third issue is that of assessment and credit. Increasingly in common with other university law schools, SOAS has pro bono options for both undergraduate and postgraduate students. But the Clinic is different: it is a fully integrated part of the School of Law's postgraduate curriculum, credit bearing and running over the two teaching terms. Giving students credit for their work is seen by some as critical to clinic development; in 2000, Grimes identified this as one of the issues remaining as a challenge for the integration of clinics across the wider curriculum in the UK. ${ }^{74}$ In an earlier piece, he had reflected that "students both demand and deserve credit for their efforts"; clinic teachers find formal assessment good for engaging and sustaining commitment, and, in my case, NGO project partners preferred on principle that the students' work was done for formal credit. ${ }^{75}$ The question for me, then, was not whether to assess the students, but how to do it; assessment of CLE work is recognized as extremely challenging. ${ }^{76} \mathrm{I}$ assessed by long essay for the first two years but, in response to student feedback, switched to include a mark for the student's Project Portfolio. This Portfolio includes a reflective presentation of the project and excerpts of the student's individual writing contribution to the final project outcome brief and annexes the full project document or report, a selfevaluation statement from the first term, and the student's Project Diary.

73 Jeff Giddings and Jennifer Lyman, Bridging Different Interests. The Contributions of Clinics to Legal Education, in The Global Clinical Movement (Frank Bloch, ed., New York: Oxford University Press 2011), 297-309, at 307. See Campbell, supra note 66, on small group work in clinic as a "paradigm of student-centred teaching." And see Dignan, supra note 40, at 76: "Collaborative work based learning enhances employability"; it is also one of the QAA "law student qualities."

74 Grimes, supra note 36, at 57. See also Combe, supra note 21, at 282; Giddings et al., supra note 28, at 10. Kerrigan and Murray (supra note 38 , at 12 ) say that "it is becoming increasingly common for clinic modules to be formal and assessed."

75 Grimes, supra note 45, at 175; Rees, supra note 39, at n6. Carney et al., supra note 17, estimated that $25 \%$ of clinical work by students was assessed, compared to $10 \%$ in 2010.

${ }_{76}$ See the Special Issue of the IJLCE (Vol.23/1 2016) comprising papers from a workshop on "Problematizing Assessment in Clinical Legal Education" and introduced by Hall Elaine Hall, The Special Issue: Problematising Assessment in Clinical Legal Education, 23 (1) IJCLE 11-4 (2016). The seminar was funded by a seminar prize awarded by the Association of Law Teachers to the University of Northumbria's clinic. 
Reflective journals are a standard of CLE practice; ${ }^{77}$ I encourage my students to use the Project Diary to $\log$ hours, activities, and ideas, as well as for reflection on the nature of the project and its place in "human rights work," but engagement with it can be uneven and making it part of the formal assessment is inevitable. The opportunity to review and radically restructure assessment is presented by SOAS's preparations to switch to the common credit framework for postgraduate courses (the European Credit and Transfer Units associated with the Bologna Process).

Kerrigan and Murray identify for the UK law student a good range of clinical and pro bono activities available at different law schools, with a focus on undergraduates. ${ }^{78}$ The key feature of a particular activity being a practice of CLE for them is that it includes reflection on the activity, and they include the following as examples of CLE: in-house advice and representation clinics, adviceonly/gateway clinics, placements and externships, street law projects, ${ }^{79}$ simulation activities, and specialist clinical projects such as Innocence Projects ${ }^{8 \circ}$ and "policy/ law reform clinics." ${ }^{81}$ At the SOAS human rights clinic, we have once placed a student team in a law firm to work on a brief, at the firm's request, but mostly the teams work from SOAS. ${ }^{82}$ We integrate skills-building classes into the weekly plenary, but we do not attempt to explicitly cover the "DRAIN" lawyering skills that may be focussed on in undergraduate CLE programmes. ${ }^{83}$ Clubb discusses

77 See for example Dignan, supra note 40, at 79; Richard Grimes, David McQuoid-Mason, Ed O’Brien, and Judy Zimmer, Street Law and Social Justice Education, in The Global Clinical Movement (Frank Bloch, ed., New York: Oxford University Press 2011), 225-40, at 234.

$7^{8}$ Twining supra note 24, and see also Let's Talk: Framing Enquiry and Discussions about "Legal Education," 49 (3) THE LAW TEACHER 388-98 (2015) has criticized what he perceives as the "absence of emphasis on postgraduate and advanced studies" in discussions of legal education and training, of the postgraduate stage.

79 On Street Law in the UK, see Richard Grimes, Legal Literacy, Community Empowerment and Law Schools - Some Lessons from a Working Model in the UK, 37 THE LAW TEACHER 273-84 (2003); and Grimes et al., supra note 77 .

8o Towards the end of March 2016, The Justice Gap posted an interview with Richard Foster, chair of the Criminal Cases Review Commission (CCRC), which included the following: "A few years ago it was claimed that university innocence projects were looking at over 100 cases. The Commission points out that in the 12 years of the innocence movement they have only received around 25 applications from universities - and half of them from one university (Cardiff). With an analogy that is not going to go down well with university innocent projects, Foster says: 'If you think that you have a terminal illness, would you rather have your case considered by medical students in the bar on Friday night - or would you rather send it to a consultant oncologist?" See http://thejusticegap .com/2016/o3/way-back-court-appeal/ (last visited April 30, 2016). Notice was promptly drawn to this on the CLEO mailing list, and The Justice Gap has a number of posts in response, many from clinic supervisors.

81 Kerrigan and Murray, supra note 38 , at 7, 2-3. Other particular clinical projects presented on the website of different UK law schools include the Essex Law Clinic's Miscarriage of Justice Project and Cardiff University's Legal Advice Scheme's partnership with the Welsh Rugby Union.

82 On this occasion, the team members were asked to sign a confidentiality agreement with the firm; compare Chapter 16 by Nollkaemper and Kjos in this volume.

83 Drafting, Research, Advocacy, Interviewing and Negotiation; see et al. supra note 49, at 37-38. 
some of the challenges that exist in a clinic such as ours at SOAS at postgraduate level and including students from different jurisdictions and non-law backgrounds; she proposes an "action research type model as a basis for the provision of postgraduate law clinic." ${ }^{\prime 4}$ In addition to Clubb’s own offering at Derby, there are recently-created LLM programmes in CLE at Ulster and in the Theory and Practice of CLE at York.

\section{Beyond the Educational Goals}

The Ulster LLM programme is framed as "access to justice through legal education," ${ }^{85}$ signalling its positioning within the older "skills v. values" debate in CLE ${ }^{86}$ A major research publication co-authored by a director of the Ulster University Law Clinic investigates precisely the issue of access to justice through clinics at university law schools and begins by noting the changes made over the past thirty years in publicly funded legal aid provision in the UK, from a system "that was regarded as one of the most generous in the world, to a rationalised provision that has seen significant reductions to both the scope of work that comes within legal aid schemes and the remuneration available to cover it." ${ }^{87}$ Indeed, many CLE and pro bono-related publications over recent years affirm the reduction in state-funded legal aid provision (including reduced funding for local advice centres and the introduction of certain court and tribunal fees) as among the contextual factors supporting the need for increased provision by university CLE programmes and pro bono commitments by the professions and those aspiring to join them, commitments that Giddings et al. note are being "vigorously promot[ed]" by the Attorney General, city law firms, and the bar, as well as by the government. ${ }^{88}$ According to Martin Barnes, Chief Executive of LawWorks, announcing the tenth round of LawWorks and Attorney General Student Pro Bono Awards in 2016:

Restrictions in legal aid and cuts in funding for local law centres have significantly reduced people's ability to access legal advice and representation, putting greater demand and pressure on pro bono services. While pro bono is not, and should not be seen as, an alternative to legal aid, law students and law schools make an

84 Clubb, supra note 49 , at 400.

85 https://www.ulster.ac.uk/courses/course-finder/201617/clinical-legal-education-9087.

86 According to Gold and Plowden (supra note 21, at 314) "a proxy for the debate over the heart and soul of the clinical movement."

87 Drummond and McKeever, supra note 13, at 8.

88 Giddings et al., supra note 28, at 10. See Martin Barnes, Foreword. In LawWorks Clinics Network Report April 2014-March 2015. LawWorks 2015, https://www.lawworks.org.uk/solicitors-and -volunteers/resources/lawworks-clinics-network-report-april-2014-march-2015 (last visited April 30, 2016); the foreword by Baroness Scotland to Kerrigan and Murray's (supra note 38) Student Guide at xviii; and Bleasdale-Hill and Wragg, supra note 18, at 257. For a direct impact see, Dignan, supra note 40 , at 76 on the ending of $£_{700,000}$ of local authority funding to the Humberside Law Centre ("now closed"). 
important contribution to enabling people to access the advice and support they need. $^{89}$

Drummond and McKeever propose that such context can in part be responded to by the academy providing students with "a learning-by-doing approach to understanding the barriers to justice, and the student/lawyer role in helping to overcome these barriers." $9 \circ$ Previously, better state-funded access to justice and legal aid provision in the UK slowed the impetus for CLE programmes; $9^{11}$ and while "radical" students and staff (e.g. in Kent and Warwick in the early 1970s) saw an improved equality agenda to be realized through clinics (and law more generally), Drummond and McKeever agree that from the 1990s:

the motivation for clinic creation has been focussed on "employability" through the acquisition of practical legal skills, and the conceptual basis of social justice has been superseded by a focus on educational priorities. While social justice can still be delivered, it tends to be as a consequence of a pedagogically focussed initiative rather than as its mission. ${ }^{92}$

In summarizing the findings from their research and based on responses from thirtytwo UK university law school clinics in a survey carried out in the summer of 2015 , they note that clinics "prioritise the objectives of improving student employability and developing professional capacity in law students over assisting local communities and delivering access to justice."93 Kerrigan and Murray take a more engaged approach than that consensus would suggest: explaining to the student readers why "the relationship between clinic and social justice is ... long-standing and deeply entrenched," they say that, in a general law degree, "students may fail to grasp the reality that legal rules and legal processes are not separate from social, political and economic relationships, but are an intrinsic part of the unequal distribution of power and resources in society." 94

\section{Internationalization, Cooperation, and Diffusion}

In the SOAS Clinic, the framing of international human rights law already pronounces something of a built-in social justice purpose - even if, for critics of human

89 https://www.lawworks.org.uk/about-us/news/nominations-open-pro-bono-lawworks-and-attorney-gen eral-student-awards-2016 (last visited April 14, 2016).

90 Drummond and McKeever, supra note 13, at 8. See more generally Frank S. Bloch and Mary Anne Noone, Legal Aid Origins of Clinical Legal Education, in The Global Clinical Movement (Frank S. Bloch, ed., New York: Oxford University Press 2011), 153-66.

91 Drummond and McKeever, supra note 13, at 12.

92 Id., at 12-13. They cite here Dignan, supra note 40, and Grimes, supra note 36.

93 Drummond and McKeever, supra note 13, at 5. They did however find agreement that CLE programmes can and do provide access to justice, a consequence of which students are a part (at 6).

94 Kerrigan and Murray, supra note 38 , at 18. 
rights, its proponents are inextricably bound up in power dynamics. ${ }^{95}$ In a human rights clinic, much as is to be expected, the thrust of most work will be taking on governments (or certain "authorities") in some way or another, in some forum or another, or at least preparing the ground for this. If it is not aimed at preparing the ground for an intervention in an international or regional forum, it may be a direct contribution to the research and advocacy work of a domestic human right group seeking legislative or policy change to bring national government(s) into greater compliance with international commitments. The partners and projects that have come to the SOAS Clinic have largely been a result of my own networks and those of close (and like-minded) friends and colleagues from the human rights movement. In the early debates over CLE in the UK, Rees identified one of the critiques made by Bankowski and Mungham of developments at the universities of Warwick and Kent as being that "the theory of society and community underlying these new developments is seldom made explicit by the harbingers of clinical training." 96 And Sherr, looking back in the mid-nineties, asked "Is it right that the clinical teachers clandestinely operated their own political agenda?"97 In the United States at the end of 2014, participants in the International Human Rights Clinicians email list ${ }^{8}$ were responding to noisy critique by Eric Posner - inter alia, that international human rights law clinics "have no pedagogic value and do nothing more than engage in 'left-wing' political activism." 99 A post by a more sympathetic reader of Posner's critique found it healthy to be reminded that such clinics "are outside the traditional box of law school clinics and that they do risk becoming a platform for pure political advocacy (and training students in pure political advocacy)." "Should law students really be training to do the same kind of stuff," $\mathrm{Ku}$ asks, as that done "within the orbit of the larger universe of UN-affiliated NGOs and UN human rights institutions?"100

95 See David Kennedy, The International Human Rights Movement: Part of the Problem?, 15 Harv. Hum. RTS. J. 101-25 (2002); The International Human Rights Regime: Still Part of the Problem?, in Examining Critical Perspectives on Human Rights (Rob Dickinson, Elena Katselli, Colin Murray and Ole W. Pederson, eds., Cambridge: Cambridge University Press 2012) 19-34; and, for one of many responses from a scholar-activist, see Christine Bell, Human Rights and the Struggle for Change: A Study in Self-Critical Legal Thought, in Examining Critical Perspectives on Human Rights (Rob Dickinson, Elena Katselli, Colin Murray and Ole W. Pederson, eds., Cambridge: Cambridge University Press 2012), 217-46.

${ }_{96}$ Rees, supra note 39, at $131 . \quad 97$ Sherr, supra note 36, at 119.

$9^{8}$ My thanks to Professor Stephanie Farrior, Director of the Center of Applied Human Rights at Vermont Law School, for getting me on to this list.

99 As summarized by Sitai Kalantry, Eric Posner Has a Narrow Understanding of Human Rights Clinics, Chronicle of Higher Education November 24, 2014, http://chronicle.com/blogs/conversa tion/2014/11/24/eric-posner-doesnt-understand-human-rights/; and Eric Posner, The Human Rights Charade, The Chronicle of Higher Education November 17, 2014.

$100 \mathrm{Ku}$, Julian. "Eric Posner's Not Completely Wrong Critique of International Human Rights Law Clinics." Opinio Juris, December 3, 2014. On line at: http://opiniojuris.org/192014/12/oz/eric-posners -not-completely-wrong-critique-international-human-rights-law-clinics/?utm_source=feedburner \&utm_medium $=$ email\&utm_campaign=Feed\%3A+opiniojurisfeed $+\% 28$ Opinio+Juris\%29. 
In the SOAS Clinic, students' reflection on their project work - and more generally on the work of human rights NGOs into which this broadens - often invokes Peter Rosenblum's argument for an "ambivalent activism": "committed to action, but alert to the multiple consequences; ... more sympathetic to the plight of people trying to do good, while at the same time more critical of those who do it without reflecting on the possible negative consequences." ${ }^{101}$ This kind of personal reflection may or may not be underpinned by broader scholarship more critical of the human rights enterprise generally, including that of my SOAS colleague Stephen Hopgood, who holds a seminar with my Clinic students every year. ${ }^{102}$ The Critical Legal Studies tradition is quite established in the SOAS School of Law, and my students over the years appear to be increasingly tending towards the underlying critique of the power dynamics of international human rights as a starting point; many of them focus on the co-optation of human rights discourse in neo-liberal agendas and neo-imperial military ventures, and some find it hard to believe that "human rights" ever held, or ever could hold, radical promise of change. In 1995, Sherr speculated that the same "ethos" and "original political objectives" that underpinned early CLE efforts and matched the "anti-authoritarian views" of that era's students "probably also gave rise to the critical legal studies movement."103 Pondering the subsequent CLE focus on skills teaching, Sherr wondered:

Is it possible to take the politics out of clinical legal education? Can they be left with the theoreticians of the critical legal studies movement and can legal skills be taught, sanitised of the ideology and devoid of the emotion? ${ }^{104}$

The recent furore around US human rights clinics might suggest not. The weight of clinic students' critique is not directed at the aspiration for change and for "social justice" but at how we might get there; the engagement with a specific project and a specific organization opens the way for application of the critique and back again to reflection, all the while fulfilling commitment to the partner by completing the work to the highest standard possible. ${ }^{105}$ The manner of the partner's engagement with the team's work is critical to the student experience. In turn, the partners' cooperation with the Clinic is based on an expectation of a serious contribution to

101 Rosenblum, supra note 19, at 304-05.

102 See Stephen Hopgood, Keepers of the Flame. Understanding Amnesty International (Cornell: Cornell University Press 2006); The Endtimes of Human Rights (New York: Cornell University Press 2013).

103 Sherr, supra note 36 , at 118.

104 Id., at 119. See Caroline Bettinger-Lopez, Davida Finger, Meetali Jain, JoNel Newman, Sarah Paoletti, Deborah M. Weissman, Redefining Human Rights Lawyering through the Lens of Critical Theory: Lessons for Pedagogy and Practice, 18 (3) Georgetown J. Poverty L. \& Pol. 337-97 (2011), for an account of the recent scholarly cooperation of a set of human rights and poverty clinicians and poverty law clinicians in examining the utility and implications of applying critical legal theory to their work.

105 Where appropriate, the Clinic teams' work is acknowledged in publications by the partners. 
their work by the Clinic team and, in some cases at least, of an engagement with potential future colleagues in the human rights movement.

\section{CONCLUSION}

At the time of writing, after the victory of the "Brexit" campaign in the referendum, ${ }^{106}$ the medium- and long-term implications of a withdrawal of the UK (or parts of it) from the EU for the higher education sector in general and for legal education and training in particular are as yet unclear. Even before the referendum, for undergraduate clinics in the UK, Campbell and Boothby find the future to be "far from clear" in light of consumerism-driven changes to legal services provision and the ramifications of registering as Alternative Business Structures. ${ }^{107}$ As already noted, Richard Wilson has suggested that human rights might be the area of law in which clinical work might take off in Council of Europe countries. ${ }^{108}$ A question for international human rights clinics in Europe is whether we have sufficient "critical mass" to begin to work together in cooperative ventures in scholarship as well as, possibly, in practice - perhaps in praxis! The issue of scholarship is key. In the UK, a number of clinical scholars have commented on the fact that in the last two Research Assessment/Excellence Exercises, on the basis of which the government decides its allocation of research funding to individual universities, publications on legal education, including scholarship on CLE, have generally not received a strong rating. According to Gold and Plowden, this illustrates a continuing "antipathy to practice-based and pedagogic materials in law."109 In the most recent exercise, the subpanel in law said that it was "pleased to receive submissions relating to legal education but the methodological rigour and significance exhibited by some of these outputs was uneven." emphasis in general law school culture from teaching to research" which he holds to be "largely attributable" to Research Excellence Framework (REF) exercises. ${ }^{11}$ The increasing attention to the "impact" of scholarship in such exercises is not straightforwardly applicable (linkable) to the work of Clinic students, no matter how demonstrable that "impact" might be. The risks here include that teaching a clinic will be detrimental to an academic lawyer's career, given the demands on the teacher, if the associated scholarship arising from the clinical experience is not "rated."112 Drummond and McKeever have suggestions as to how to take the scholarship forward, as do Gold and Plowden, ${ }^{113}$ and, possibly, cooperation between clinic

106 On June 23, 2016.

107 Under the Legal Services Act 2007. \#\# Elaine Campbell and Carol Boothby, University Law Clinics as Alternative Business Structures: More Questions than Answers?, 50 (1) The LaW Teacher 132-37 (2016), at 137; Leighton, supra note 35, at 80.

108 Wilson, supra note 4, at 828. 109 Gold and Plowden, supra note 21, at 316.

11 Research Excellence Framework 2014: Overview Report, Sub-Panel 20: Law, 71, para. 6

${ }_{111}$ Twining, supra note 28, at 389 n3. ${ }^{112} \quad$ See Giddings et al., supra note 28, at 16.

113 Drummond and McKeever, supra note 13, at 13; Gold and Plowden, supra note 21, at 316-20. 
convenors in different parts of Europe might have contributions to make here. In the UK, a more recent governmental initiative in the field of surveillance of academic effort, the Teaching Excellence Framework (TEF), might be expected to rate CLE programmes quite healthily, and an earlier optimistic projection suggested that more university law schools would start to offer clinical options of some sort because those not doing so would find themselves disadvantaged in the increasingly competitive market of law student recruitment. ${ }^{114}$ However, this by no means implies a reconciliation between the demands of teaching and the expectations of research for the individual clinic teacher.

\section{References}

ACLEC (Lord Chancellor's Advisory Committee on Legal Education and Conduct). Annual Report for 1993-1994. London: HMSO, 1994.

Amnesty International, Below the Radar, 5 April 2006 (AI Index AMR 51/051/2006).

Bankowski, Zenan, and Geoff Mungham. "'Warwick University Ltd.' (Continued).” 1 British Journal of Law and Society 1974 179-84.

Bar Standards Board and Solicitors Regulation Authority. Academic Stage Handbook (v. 1.4). July 2014 [on line].

Barnes, Martin. "Foreword." In LawWorks Clinics Network Report April 2014-March 2015. LawWorks 2015: available at https://www.lawworks.org.uk/solicitors-and-volunteers /resources/lawworks-clinics-network-report-april-2014-march-2015 [last accessed 30 April 2016]

Bell, Christine. "Human Rights and the Struggle for Change: A Study in Self-Critical Legal Thought." In Examining Critical Perspectives on Human Rights, eds. Rob Dickinson, Elena Katselli, Colin Murray and Ole W. Pederson, 217-46. Cambridge: CUP, 2012.

Benneworth, Paul and Michael Osborne. Knowledge, Engagement and Higher Education: Contributing to Social Change. In Higher Education in the World 5, 219-32. Global University Network for Innovation, 2014.

Bettinger-Lopez, Caroline, Davida Finger, Meetali Jain, JoNel Newman, Sarah Paoletti, Deborah M. Weissman. "Redefining Human Rights Lawyering through the Lens of Critical Theory: Lessons for Pedagogy and Practice." Georgetown Journal on Poverty Law and Policy XVIII/3 (2011) 337-397.

Bleasdale-Hill, Lydia and Pail Wragg. "Models of Clinic and Their Value to Students, Universities and the Community in the post-2012 Fees Era." IJCLE 19 (2013) 257-69.

Bloch, Frank S. and Mary Anne Noone. "Legal Aid Origins of Clinical Legal Education." In The Global Clinical Movement, ed. Frank S. Bloch, 153-66. New York: OUP 2011.

Bradney, Anthony. "Ivory Towers and Satanic Mills: Choices for University Law Schools." Studies in Higher Education 17/1 (1992) 5-20.

Campbell, Elaine. "Transferring Power: A Reflective Exploration of Authentic Student-Centred Small Group Work in Clinical Legal Education.” IJCLE 22 (2015) 1-31.

Campbell, Elaine and Carol Boothby. "University Law Clinics as Alternative Business Structures: More Questions than Answers?” The Law Teacher 50:1 (2016) 132-37.

Carillo, Arturo J. "Bringing International Law Home: The Innovative Role of Human Rights Clinics in the Transnational Legal Process." Colum H. Rts. L. Rev. 35 (2003-2004) $527-87$. 
Carney, Damian, Frank Dignan, Richard Grimes,Grace Kelly, Rebecca Parker. The LawWorks Law School Pro Bono and Clinic Report 2014. LawWorks: LexisNexis (2014) on-line at: https://www.lawworks.org.uk/sites/default/files/LawWorks-student-pro-bono -report\%202014.pdf

Chavkin, David. "Thinking/Practicing Clinical Legal Education from within the Palestinian-Israeli Conflict: Lessons from the Al-Quds Human Rights Clinic." Human Rights Brief 18 (2010) 14-18.

Clubb, Karen. "Masters of Our Destiny - The Integration of Law Clinic into Postgraduate Masters Provision.” IJCLE 19 (2013) 395-404.

CMND 4595 1971. Report of the Committee on Legal Education.

Combe, Malcolm M. "Selling Intra-curricular Clinical Legal Education.” The Law Teacher $48: 3$ (2014) 281-95.

Dignan, Frank. "Bridging the Academic/Vocational Divide: The Creation of a Law Clinic in an Academic Law School." IJCLE 16 (2011) 75-84.

Drummond, Orla and Gráinne McKeever. Access to Justice through University Law Clinics. Ulster: Ulster University Law School, 2015. On-line at: www.ulster.ac.uk/lawclinic/files /2014/o6/Access-to-Justice-through-Uni-Law-Clinics-November-2015.pdf

Folsom, Ralph and Neal Roberts. "The Warwick Story: Being Led down the Contextual Path of the Law." Journal of Legal Education 30 (1979) 166-83.

Giddings, Jeff. "The Assumption of Responsibility: Supervision Practices in Experiential Legal Education." In Experimental Legal Education in a Globalized World. The Middle East and Beyond, ed. Mutaz M. Qafisheh and Stephen A. Rosenbaum, 29-52. Newcastle upon Tyne: Cambridge Scholars Publishing, 2016.

Giddings, Jeff, Roger Burridge, Shelley A.M. Gavigan and Catherine F. Klein. "The First Wave of Clinical Legal Education. The United States, Britain, Canada and Australia.” In The Global Clinical Movement, ed. Frank Bloch, 3-22. New York: OUP, 2011.

Giddings, Jeff and Jennifer Lyman. "Bridging Different Interests. The Contributions of Clinics to Legal Education.” In The Global Clinical Movement, ed. Frank Bloch, 297-309. New York: OUP, 2011.

Gold, Neil. "Why Not an International Journal of Clinical Legal Education?" IJCLE 1 (2000) 7-12.

Gold, Neil and Philip Plowden. "Clinical Scholarship and the Development of the Global Clinical Movement.” In The Global Clinical Movement, ed. Frank Bloch, 311-21. New York: OUP, 2011.

Gowland, Judith and Paul McKeown. "Working with Your Supervisor and Others." In A Student Guide to Clinical Legal Education and Pro Bono, eds. Kevin Kerrigan and Victoria Murray, 88-106. Houndmills: Palgrave Macmillan, 2011.

Grimes, Richard. "Reflections on Clinical Legal Education." The Law Teacher 29 (1995) $169-88$.

“The ACLEC Report - Meeting Legal Education Needs in the 21st Century?" Legal Education Review 7: 2 (1996) 281-89.

"Learning Law by Doing Law in the UK." IJCLE 1 (2000) 54-57.

"Legal Literacy, Community Empowerment and Law Schools - Some Lessons from a Working Model in the UK." The Law Teacher 37 (2003) 273-84.

Grimes, Richard, Joel Klaff and Colleen Smith. "Legal Skills and Clinical Legal Education A Survey of Undergraduate Law School Practice." The Law Teacher 30 (1996) 44-67.

Grimes, Richard, David McQuoid-Mason, Ed O'Brien and Judy Zimmer. "Street Law and Social Justice Education.” In The Global Clinical Movement, ed. Frank Bloch, 225-40. New York: OUP, 2011. 
Hall, Elaine. "The Special Issue: Problematising Assessment in Clinical Legal Education.” IJCLE 23/1 (2016) 11-4.

Hopgood, Stephen. Keepers of the Flame. Understanding Amnesty International. Cornell: Cornell University Press, 2006.

The Endtimes of Human Rights. New York: Cornell University Press, 2013.

Hurwitz, Deena. "Lawyering for Justice and Inevitability of International Human Rights Clinics." Yale Journal of International Law 28 (2003) 505-550.

Kalantry, Sitai. "Eric Posner Has a Narrow Understanding of Human Rights Clinics." Chronicle of Higher Education 24 November 2014: on-line at http://chronicle.com /blogs/conversation/2014/11/24/eric-posner-doesnt-understand-human-rights/

Kennedy, David. “The International Human Rights Movement: Part of the Problem?” 15 Harvard Human Rights Journal (2002) 101-25.

“The International Human Rights Regime: Still Part of the Problem?" In Examining Critical Perspectives on Human Rights, eds. Rob Dickinson, Elena Katselli, Colin Murray and Ole W. Pederson, 19-34. Cambridge: CUP, 2012.

Kerrigan, Kevin and Victoria Murray, eds. A Student Guide to Clinical Legal Education and Pro Bono. Houndmills: Palgrave Macmillan, 2011.

Kerrigan, Kevin. "What Is Clinical Legal Education and Pro Bono?" in A Student Guide to Clinical Legal Education and Pro Bono, ed. Kevin Kerrigan and Victoria Murray, 1-20. Houndmills: Palgrave Macmillan, 2011.

Ku, Julian. "Eric Posner's Not Completely Wrong Critique of International Human Rights Law Clinics." Opinio Juris, 3 December 2014. On line at: http://opiniojuris.org/ 192014 /12/o3/eric-posners-not-completely-wrong-critique-international-human-rights-law -clinics/?utm_source=feedburner\&utm_medium=email\&utm_campaign=Feed\%3A + opiniojurisfeed $+\% 280$ pinio $+J u r i s \% 29$

Leighton, Patricia. "Back from the Future: Did the LETR Really Prepare Us for the Future?" The Law Teacher 48 (2014) 79-93.

Marson, James, Adam Wilson, Mark Van Hoorebeck. "The Necessity of Clinical Legal Education in University Law Schools: A UK Perspective.” IJCLE 7 (2005) 29-43.

McAllister, Lindy, Michelle Lincoln, Sharyne McLeod, Diana Maloney (eds.). Facilitating Learning in Clinical Settings. Cheltenham: Nelson Thornes Ltd 2001 (original print 1997).

Posner, Eric. The Twilight of International Human Rights Law. New York: OUP, 2014.

Qafisheh, Mutaz. "Modern Legal Education in Palestine: The Clinical Programs of Hebron University." In Experimental Legal Education in a Globalized World. The Middle East and Beyond, ed. Mutaz M. Qafisheh and Stephen A. Rosenbaum, 198-235. Newcastle upon Tyne: Cambridge Scholars Publishing, 2016.

Rees, William M. "Clinical Legal Education: An Analysis of the University of Kent Model." The Law Teacher 9 (1975) 125-40.

Research Excellence Framework 2014. Overview Report by Main Panel C and Sub-Panels 16-26. January 2014.

Rosenblum, Peter. "Teaching Human Rights: Ambivalent Activism, Multiple Discourses and Lingering Dilemmas.” Harvard Human Rights Journal 15 (2002) 301-15.

Sherr, Avrom. Clinical Legal Education at Warwick and the skills Movement: Was Clinic a Creature of its Time." In Frontiers of Legal Scholarship. Twenty Five Years of Warwick Law School, ed. Geoffrey P. Wilson, 108-19. Chichester: John Wiley and Sons, 1995.

Twining, William. "LETR: The Role of Academics in Legal Education and Training: 10 Theses." The Law Teacher 48:1 (2014) 94-103. 
“Let's Talk: Framing Enquiry and Discussions about 'Legal Education'." The Law Teacher 49: $3(2015) 388-98$.

Webb, Julian. "Inventing the Good: A Prospectus for Clinical Education and the Teaching of Legal Ethics in England." 30 Law Teacher (1996) 270-94.

Webb, J., J. Ching, P. Maharg and A. Sherr, Setting Standards: The Future of Legal Services Education and Training Regulation in England and Wales. London: Legal Education and Training Review, 2013.

Welchman, Lynn and Sara Hossain, eds. "Honour": Crimes, Paradigms and Violence Against Women. London: Zed Books, 2005.

Wilson, Richard J. "Western Europe: Last Holdout in the Worldwide Acceptance of Clinical Legal Education." German Law Journal 10:7 (2009) 823-46.

"Introductory Remarks." American Society of International Law Proceedings 2010 "Teaching International Law: Lessons from Clinical Education" 87-88. 